\title{
Morphometric Analysis of the Nira River Basin in Maharashtra State, India using Geographical Information System
}

\author{
R. S. Shelar* and S. S. Mane \\ College of Agriculture Engineering and Technology, Dapoli (M.S.), India \\ *Corresponding author
}

\section{A B S T R A C T}

\section{Keywords}

Morphometric analysis, Geospatial techniques, Nira river basin,

Remote sensing

\section{Article Info}

Accepted:

04 October 2019

Available Online:

10 November 2019
Morphometric analysis was carried out to analyse and determine the drainage pattern and morphometric characteristics of Nira river basin using topographical maps, SRTM data and geo-spatial technique. The study area, Nira river basin is one of the major tributary of Bhima river basin in Pune district of Maharashtra and it has drainage area 6879.60 sq. km. Morphometric parameters like stream order, stream length, bifurcation ratio, drainage density, stream frequency, relief ratio, elongation ratio and circularity ratio are calculated using various techniques. The morphometric analysis carried out in the Nira river basin shows that the basin is elongated basin indicating that the basin may produce flatter peak of flood for a longer duration. The basin has undulating topography. The high relief indicates that Nira river basin has a steep slope. The drainage density of the basin is $0.39 \mathrm{~km} / \mathrm{sq}$. $\mathrm{km}$. It is concluded that remote sensing and GIS have been proved to be efficient tools in drainage delineation and updation. In the present study, these updated drainages have been used for the morphometric analysis.

\section{Introduction}

Morphometric analysis using remote sensing data and geo-spatial technique has emerged as a powerful tool in recent years. Remote sensing has the ability of obtaining synoptic view of the large area at one time and very useful in analysing the drainage morphometry. Morphometry is the measurement and mathematical analysis of the configuration of the earth's surface, shape and dimension of its landforms (Clarke, 1966). This analysis can be achieved through measurement of linear, aerial and relief aspects of the basin and slope contribution (Nag and Chakraborty, 2003).

River basin morphometric elements provide valuable information for groundwater potential, runoff and geographic characteristics of the drainage basin. The 
morphometric analysis of the drainage basin and channel network play a significant role in understanding the geo-hydrological behaviour of the drainage basin and expresses the prevailing climate, geology, geomorphology, structural antecedents of the catchment. It finds out geomorphologic and structural control of flow, runoff and helps predict floods, their extent and intensity. These studies are very useful for identifying and planning the groundwater potential zones and watershed management, including the whole extent of natural resources connected with the watershed. To prepare a comprehensive watershed development plan, it becomes necessary to understand the topography, erosion status and drainage pattern of the region. For detailed morphometric analysis, we used SRTM data for preparing DEM map, slope and aspect maps. GIS was used in the evaluation of linear, areal and relief morphometric parameters.

The present study area, Nira river basin is a major tributary of Bhīma River which flows through the state of Maharashtra. The drainage area of Nira river basin covers the three districts of Maharashtra state where it is used as a water supply for a variety of agricultural fields, industrial purposes and also a major source for the water supply to Pune, Solapur and Satara districts. The main objective of this study, using advanced remote sensing and GIS technology is to compute basin morphometric characteristics of Nira river basin for various parameters.

\section{Materials and Methods}

\section{Study area}

Nira is a river flows through the Indian state of Maharashtra. It is a tributary of the Bhimariver and flows through Pune and Solapur districts of Maharashtra. The Nira river basin lies between the latitude $18^{\circ}$
13.528 $\mathrm{N}$ and $17^{\circ} 58.237^{\prime} \mathrm{N}$ and longitude $73^{\circ} \quad 32.357^{\prime} \mathrm{E}$ and $75^{\circ}$ 8.458' E. The basin has drainage area $6,879.60 \mathrm{~km}^{2}$. Nira basin comes under hot semi-arid climate bordering with tropical wet and dry with average temperatures ranging between 20 and $28{ }^{\circ} \mathrm{C}$ (68 and $82{ }^{\circ} \mathrm{F}$ ). Most of the $722 \mathrm{~mm}$ (28.43 in) of annual rainfall in the city falls between June and September, and July is the wettest month of the year. The location map of study area is shown in Figure 1.

\section{Database}

Data required for the present study was toposheets and Digital Elevation Model (DEM). Toposheet of the study was obtained from the official website of Survey of India (SOI). To cover the entire study area 16 toposheet were required (Table 1). The digital elevation model was used generated from Shuttle Radar Terrain Mapper (SRTM) data.

\section{Geomorphological characteristics}

Morphological characterization is the systematic description of watershed's geometry. This helps in understanding watershed characteristics which are responsible for distinct hydrologic behaviour. The geometry of drainage basin and its stream channel system requires the following measurements (Singh, 2003):

\section{Linear aspect of drainage network}

Areal aspect of drainage basin

Relief aspect of channel network and contributing ground slopes

Where,

$\mathrm{Lu}=$ Total stream length of order $\mathrm{u}, \mathrm{Nu}=$ Total no. of stream segments of order $\mathrm{u}, \mathrm{Lu}-1=$ Total stream length of its next lower order, $\mathrm{P}=$ 
Perimeter $(\mathrm{km}), \mathrm{Nu}+1=$ Number of segments of the next higher order, $\mathrm{H}=$ Total relief (Relative relief) of the basin in kilometer, Lb $=$ Basin length $(\mathrm{km}), \mathrm{A}=$ Area of the Basin $\left(\mathrm{km}^{2}\right), \mathrm{Pi}=$ 'Pi' value i.e. $3.14, \mathrm{~N} 1=$ Total no. of first order streams (Table 2).

\section{Results and Discussion}

The drainage map of the study area was prepared from the toposheets. Nira river basin was elongated shape with well-developed drainage network up to $5^{\text {th }}$ stream order in the total area $6879.60 \mathrm{~km}^{2}$. Geomorphological characteristics of the Nirariver basin are shown in Table 3 and drainage network of the study area is shown in Figure 2.

\section{Linear aspects of drainage networks}

The linear aspects of a catchment are mainly related to the characteristics of its drainage network, which in turn are influenced by the local topography (Radwan et al., 2017).

The linear aspects considered in this study include stream order, stream number, stream length, mean stream length, stream length ratio and bifurcation ratio. The stream network map of Nira river basin is shown in Figure 2.

The first step in drainage catchment analysis is determination of stream order. The ranking of streams was carried out based on the method proposed by Strahler (1964). From Table 3 it is observed that, as the stream order increases the number of streams decreases and vice versa. The number of streams was determined by adopting the standard method proposed by Horton, 1945. In the case of Nira river basin, the total number of streams (601) divided into 5 streams. Out of total number of streams 78.5 $\%$ are first order segments. This is extremely important in investing getting river basin characteristics such as drainage pattern (Waikar and Nilawar, 2014; Kant et al., 2015).
Generally, long stream lengths are an indicator of flatter gradient. The stream lengths of firstand second-order streams are 1407.34 and $737.32 \mathrm{~km}$, respectively. Total length of stream decreases with increase in order of stream. The same finding was reported by Strahler in 1964. Mean stream length is closely related to the drainage network and its associated surfaces (Strahler, 1964). In the case of the Nira river basin area, the mean stream length is 2.98 and $179.98 \mathrm{~km}$ for the first and fifth orders, respectively. This result follows the Horton's law (Horton, 1945). Stream length ratio of V/IV order was 2, IV/III order was 0.29 , III/II order was 0.41 and II/I order was 0.52 . These variations in stream length ratio in the study area were due to variations in slope and topography.

Bifurcation ratio of Nira river basin was evaluated by adopting the standard formula given by Schumm (1956). They varied from 4.82 to 3 for first to fifth order with mean bifurcation ratio of basin 5.11. In the study area, values of bifurcation ratio indicate that basin has undulating topography.

\section{Areal aspects of drainage networks}

The areal aspects of morphometric analysis of drainage basin include form factor, circulatory ratio, elongation ratio, drainage density and constant of channel maintenance. The slope map of study area is shown in Figure 3.

The values of the areal morphometric parameters obtained for the Nira river basin area are presented in Table 3. The catchment total area is $6879.6 \mathrm{~km}^{2}$ with a length of $173.59 \mathrm{~km}$ and a perimeter of $522.53 \mathrm{~km}$. The form factor value of Nira river basin was 0.23. The lower value of form factor represents elongated shape of watershed. The elongated basin with low form factor indicated that the basin may produce flatter peak of flood for longer duration. 
Table.1 Toposheets required for study area

\begin{tabular}{|c|c|c|c|c|c|c|c|}
\hline $\mathbf{4 7 F} / 11$ & $\mathbf{4 7 F} / \mathbf{1 2}$ & $\mathbf{4 7 F} / \mathbf{1 5}$ & $\mathbf{4 7 F} / \mathbf{1 6}$ & $\mathbf{4 7 J / 3}$ & $\mathbf{4 7 J} / \mathbf{4}$ & $\mathbf{4 7 J} / \mathbf{7}$ & $\mathbf{4 7 J / 8}$ \\
\hline $\mathbf{4 7 J} / \mathbf{1 1}$ & $47 \mathrm{~J} / 12$ & $47 \mathrm{~J} / 16$ & $47 \mathrm{~K} / 5$ & $47 \mathrm{~K} / 9$ & $47 \mathrm{~K} / 13$ & $47 \mathrm{~N} / 4$ & $47 \mathrm{O} / 1$ \\
\hline
\end{tabular}

Table.2 Formulae for computation of morphometric parameters

\begin{tabular}{|c|c|c|}
\hline Parameter & Formula & \multirow[t]{2}{*}{ Strahler (1964) } \\
\hline Steam Order & Hierarchical rank & \\
\hline Mean Steam Length(Lsm) & $\mathrm{Lsm}=\mathrm{Lu} / \mathrm{Nu}$ & \multirow[t]{3}{*}{ Horton (1945) } \\
\hline Stream Length Ratio (RL) & $\mathrm{RL}=\mathrm{Lu} / \mathrm{Lu}-1$ & \\
\hline Length of Overland Flow (Lg) & $\operatorname{Lg}=1 / \mathrm{Dd}^{*} 2$ & \\
\hline Bifurcation Ratio (Rb) & $\mathrm{Rb}=\mathrm{Nu} / \mathrm{Nu}+\mathrm{l}$ & \multirow{3}{*}{$\begin{array}{l}\text { Schumn } \\
\text { (1956) }\end{array}$} \\
\hline Relief Ratio (Rh) & $\mathrm{Rh}=\mathrm{H} / \mathrm{Lb}$ & \\
\hline Elongation Ratio (Re) & $\operatorname{Re}=(2 / \mathrm{Lb})^{*}(\mathrm{~A} / \mathrm{Pi})^{0.5}$ & \\
\hline Mean Bifurcation Ratio (Rbm) & $\begin{array}{c}\mathrm{Rbm}=\text { Average } \mathrm{Rb} \text { of all } \\
\text { orders }\end{array}$ & Strahler (1957) \\
\hline Drainage Density (Dd) & $\mathrm{D}=\mathrm{Lu} / \mathrm{A}$ & \multirow[t]{3}{*}{ Horton (1932) } \\
\hline Stream Frequency (Fs) & $\mathrm{Fs}=\mathrm{Nu} / \mathrm{A}$ & \\
\hline Form Factor (Rf) & $\mathrm{Rf}=\mathrm{A} / \mathrm{Lb}^{2}$ & \\
\hline Circulatory Ratio (Rc) & $\mathrm{Rc}=4 * \mathrm{Pi} * \mathrm{~A} / \mathrm{P}^{2}$ & Miller (1953) \\
\hline Textural Ratio (T) & $\mathrm{T}=\mathrm{N} 1 / \mathrm{P}$ & Nookaratnam et al., (2005) \\
\hline
\end{tabular}

Fig.1 Location map of study area

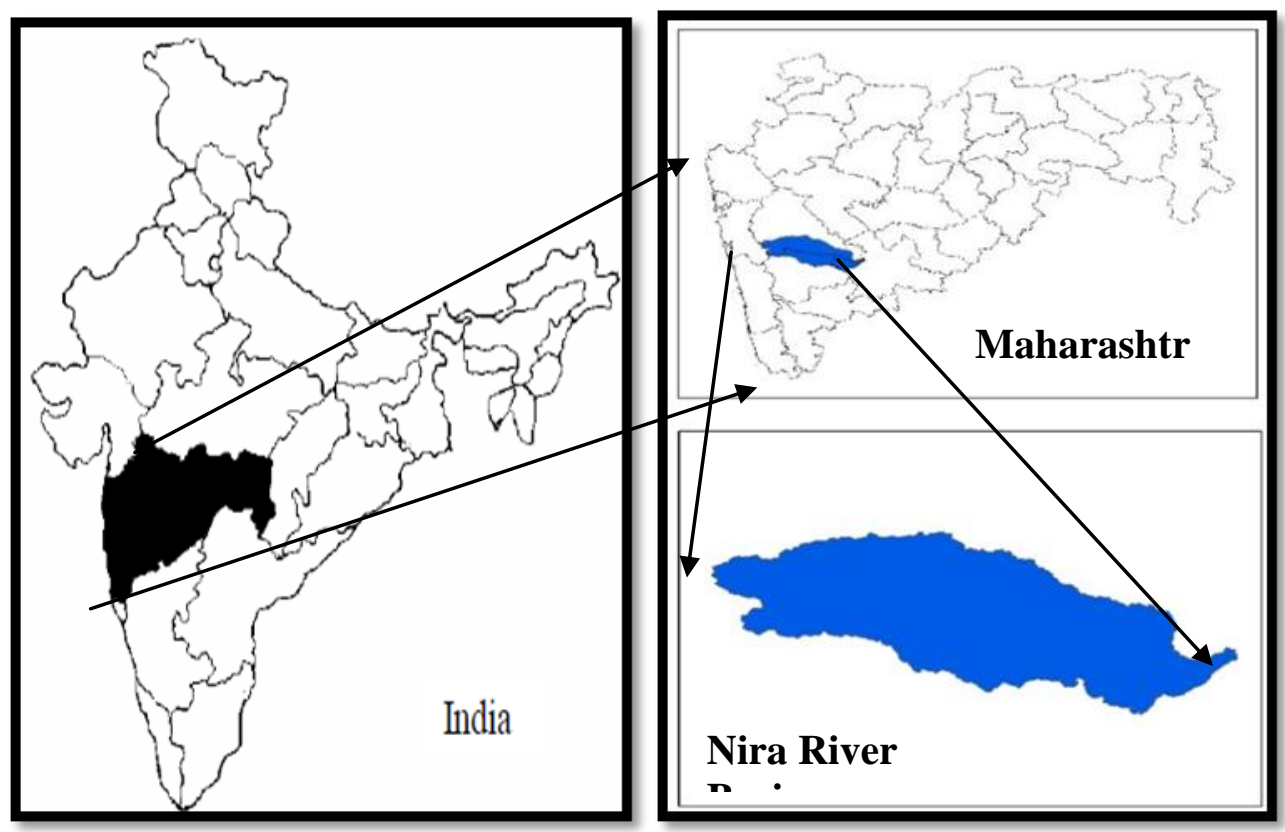


Table.3 Geomorphological characteristics of Nira river basin

\begin{tabular}{|c|c|c|c|}
\hline \multicolumn{4}{|c|}{ A) Linear aspects of drainage networks } \\
\hline Stream order & Number of streams & $\begin{array}{c}\text { Total stream length } \\
(\mathbf{k m})\end{array}$ & $\begin{array}{c}\text { Mean stream length } \\
(\mathbf{k m})\end{array}$ \\
\hline 1 & 472 & 1407.35 & 2.98 \\
\hline 2 & 98 & 737.33 & 7.52 \\
\hline 3 & 27 & 299.55 & 11.09 \\
\hline 4 & 3 & 89.78 & 29.93 \\
\hline 5 & 1 & 179.98 & 179.98 \\
\hline \multicolumn{4}{|c|}{ Bifurcation ratio } \\
\hline $1^{\text {st }}$ order $/ 2^{\text {nd }}$ order & $2^{\text {nd }}$ order $/ 3^{\text {rd }}$ order & $3^{\text {rd }}$ order $/ 4^{\text {th }}$ order & $4^{\text {rd }}$ order $/ 5^{\text {th }}$ order \\
\hline 4.82 & 3.63 & 9 & 3 \\
\hline \multicolumn{2}{|c|}{ Mean bifurcation ratio } & \multicolumn{2}{|c|}{5.11} \\
\hline \multicolumn{4}{|c|}{ Stream length ratio } \\
\hline $2^{\text {nd }}$ order $/ 1^{\text {st }}$ order & $3^{\text {rd }}$ order $/ 2^{\text {nd }}$ order & $4^{\text {th }}$ order $/ 3^{\text {rd }}$ order & $5^{\text {th }}$ order $/ 4^{\text {th }}$ order \\
\hline 0.52 & 0.41 & 0.30 & 2 \\
\hline \multicolumn{2}{|c|}{ Stream Frequency } & \multicolumn{2}{|c|}{0.87} \\
\hline \multicolumn{2}{|c|}{ Textural ratio } & \multicolumn{2}{|c|}{1.15} \\
\hline \multicolumn{4}{|c|}{ B) Areal Aspects of drainage networks } \\
\hline \multicolumn{2}{|c|}{ Area } & \multicolumn{2}{|c|}{$6879.60 \mathrm{~km}^{2}$} \\
\hline \multicolumn{2}{|c|}{ Perimeter } & \multicolumn{2}{|c|}{$522.53 \mathrm{~km}$} \\
\hline \multicolumn{2}{|c|}{ Length of Basin } & \multicolumn{2}{|c|}{$173.59 \mathrm{~km}$} \\
\hline \multicolumn{2}{|c|}{ Form Factor } & \multicolumn{2}{|c|}{0.23} \\
\hline \multicolumn{2}{|c|}{ Circulatory Ratio } & \multicolumn{2}{|c|}{0.31} \\
\hline \multicolumn{2}{|c|}{ Elongation Ratio } & \multicolumn{2}{|c|}{0.54} \\
\hline \multicolumn{2}{|c|}{ Drainage Density } & \multicolumn{2}{|c|}{$0.39 \mathrm{~km} / \mathrm{km}^{2}$} \\
\hline \multicolumn{2}{|c|}{ Constant of Channel Maintenance } & \multicolumn{2}{|c|}{$2.53 \mathrm{~km}$} \\
\hline \multicolumn{4}{|c|}{ C) Relief aspects of drainage networks } \\
\hline \multicolumn{2}{|c|}{ Relief } & \multicolumn{2}{|c|}{$959 \mathrm{~m}$} \\
\hline \multicolumn{2}{|c|}{ Relief Ratio } & \multicolumn{2}{|c|}{0.0055} \\
\hline \multicolumn{2}{|c|}{ Ruggedness number } & & \\
\hline Length of & erland Flow & & \\
\hline
\end{tabular}


Fig.2 Stream network map of Nira River Basin

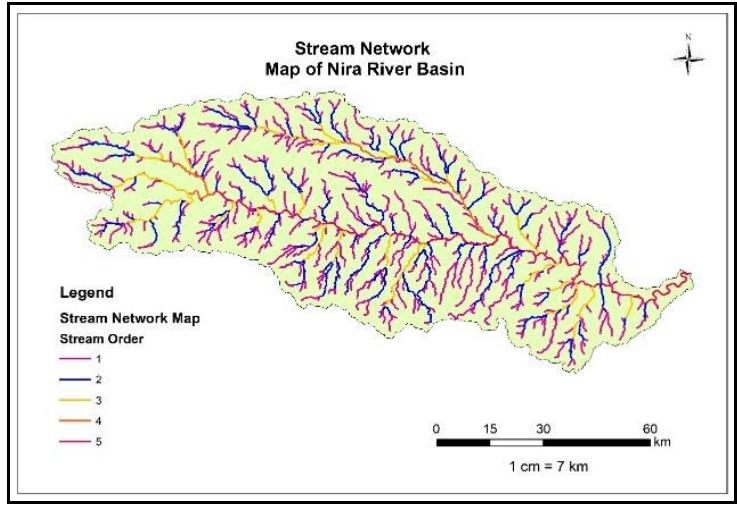

Fig.3 Slope map of Nira River Basin

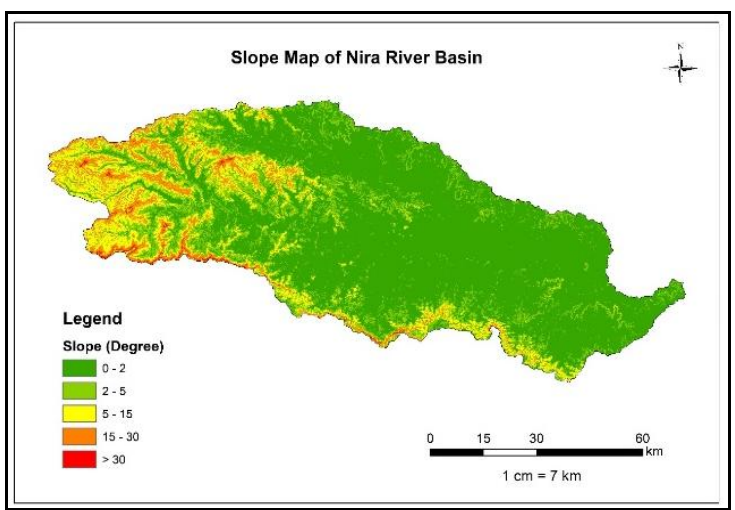

Fig.4 Relief pattern map of Nira River Basin

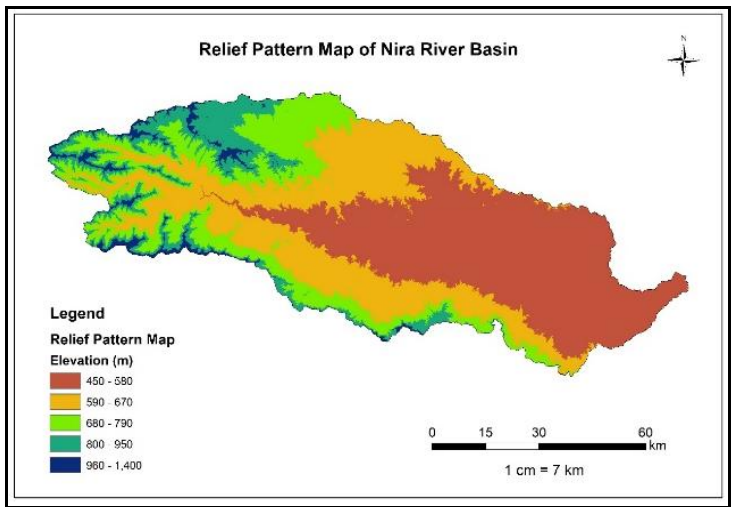

Flood flows in such elongated basins are easier to manage than of the circular basin (Kant et al., 2015). The elongation and circularity ratios of the Nira river basin are 0.54 and 0.31 , respectively. These values further confirm the elongated shape of the river basin. The circulatory ratio of Nira river basin was 0.31. It confirms the basin is elongated in shape and characterised by the high to moderate relief and the drainage system were structurally controlled. The drainage density of Nira river basin was 0.39 
$\mathrm{km} / \mathrm{km}^{2}$. The low drainage density was due to the regions of highly resistant or permeable subsoil material, dense vegetation and low relief (Strahler, 1957). The constant of channel maintenance was found $2.53 \mathrm{~km}$ for Nira river basin. Constant of channel maintenance indicates that magnitude of surface area of watershed required sustaining unit length of stream segment.

\section{Relief aspects of drainage networks}

Relief aspects of the watershed plays an important role in drainage development, surface and sub-surface water flow, permeability, landform development and associated features of the terrain. The relief pattern map of Nira river basin is shown in Figure 4. Form Table 3 it is observed that the total relief for Nira river basin was $959 \mathrm{~m}$. This indicates that Nira river basin has high relief and steep slope. The high relief value indicates the high volume flow, low infiltration and high runoff conditions of the study area. The relief ratio was 0.0055 for Nira river basin. The relief ratio normally increases with decreasing drainage area and the size of the watershed of a drainage basin. The low relief ratio of the basin indicates presence of less resistant rocks in the study area (Sreedevi, 1999).

In the present study, ruggedness number was 2.43. This indicates that the area is extremely rugged with high relief and high stream density. The length of the overland flow is the length of water over the ground before it gets concentrated into definite stream channel. The length of overland flow of the Nira river basin was $1.26 \mathrm{~km}^{2} / \mathrm{km}$.

The morphometric analysis of river basin using RS and GIS technique is a powerful tool in river basin management and planning, watershed prioritization, soil and water conservation, and management of natural resources at diverse levels. The morphometric analysis carried out in the Nira river basin shows that the basin is elongated basin with low form factor indicated that the basin may produce a flatter peak of flood for a longer duration. The high mean bifurcation ratio in the study area indicates that the basin has undulating topography. The high relief value indicates the high volume flow, low infiltration and high runoff conditions of the study area. This study would help the local people and stakeholder to understand the influence of drainage morphometric network on landforms and helps predict floods, their extent and intensity.

\section{References}

Clarke, J.I. (1996). Morphometry from Maps, Essays in Geomorphology, Elsevier publication. Co, New York, pp 235274.

Horton, R. E. (1945). Erosional development of streams and their drainage basins: Hydrophysical approach to quantitative morphology. Geol. Soc. Am. Bull, 56: 275-370.

Horton, R.E. (1932). Drainage basin characteristics. Am. Geophys. Union, Trans.; 13: 348-352.

Kant S,Meshram S, Dohare R, Singh S. (2015). Morphometric analysis of Sonar sub-basin using SRTM data and geographical information system (GIS). Afr. J. Agric. Res. 10:14011406.

Miller, V.C., (1953). A quantitative geomorphic study of drainage basin characteristics in the Clinch Mountain area, Varginia and Tennessee, Project NR 389042, Tech. Rept. 3.,Columbia University, Department of Geology, ONR, Geography Branch, New York.

Nag, S.K. and Chakraborthy. S. (2003). Influence of rock types and structures in the development of Drainage 
Network in Hard Rock Area. Journal of Indian Society of Remote Sensing, 31(1), pp 2535.

Nookaratnam, K., Y. K. Srivastav, K.S.R. Murthy, E. amminedu and V. Venkateswararao. (2005). Check dam positioning by prioritization micro watersheds using SYI model and morphometric analysis - Remote Sensing and GIS perspective. Journal of the Indian Society of Remote Sensing, Vol. 33(I).

Radwan F., Alazba A. A., and Amr Mossad. (2017). Watershed morphometric analysis of WadiBaish Damcatchment area using integrated GIS-based approach. Arab. J. Geosci.10: 256.

Schumn, S.A. (1956). Evolution of drainage systems and slopes in badlands at Perth Amboy, New Jersey. Geol. Soc. Am. Bull, 67:597- 646.

Singh, R. (2003). Watershed Planning and Management. Yash publishing house,
Bikaner, India.

Sreedevi, P.D. (1999). Assessment and land management of groundwater resources of Pageru river basin, Cuddapah district, Andhra Pradesh, India. Unpublished Ph.D. Thesis, submitted to Sri Venkateswara University, Triputi.

Strahler, A. N. (1957). Quantitative analysis of watershed geomorphology. Trans. Am. Geophys. Union, 38:913-920.

Strahler, A. N. (1964). Quantitative geomorphology of drainage basins and channel networks. In: Handbook of applied hydrology. Chow VT, (ED) McGraw Hill Book Company, New York. Pp. 4-11.

Waikar M. and Nilawar A. P. (2014). Morphometric analysis of a drainage basin using geographical information system: a case study. Int. J. Multidiscip. Curr. Res. 2:179-184.

\section{How to cite this article:}

Shelar, R. S. and Mane, S. S. 2019. Morphometric Analysis of the Nira River Basin in Maharashtra State, India using Geographical Information System. Int.J.Curr.Microbiol.App.Sci. 8(11): 59-66. doi: https://doi.org/10.20546/ijcmas.2019.811.007 